\title{
MACROECONOMIC AND BANK SPECIFIC DETERMINANTS OF NON-PERFORMING LOANS (NPLS) IN THE INDIAN BANKING SECTOR
}

\author{
MEMDANI Laila \\ IBS Hyderabad, IFHE University, India
}

\begin{abstract}
:
The main objective of the paper is to find out the determinants of NPAs in the Indian Banking sector and to study if these determinants vary across the three different ownership structures viz., public sector banks (PSBs), private banks (PBs) and foreign banks (FBs), of banks in India. The panel data for all the banks from 2005 to 2014 is collected from the official website of Reserve Bank of India (RBI), the Central Bank of the country. The econometric technique of Fixed Effects model and Random Effects model is used for the purpose. The results reveal that Macro economic factors, like log of percapita income (LPCY) and Inflation (INFN), are significantly affecting NPLs in Public Sector Banks (PSBs). In case of private banks (PBs) LPCY is highly significant while bank specific variables like size and total loans to total loans of the banking sector (TLTLBS) are significant at $10 \%$ level. For FBs none of the variables were significant.
\end{abstract}

Key words: Non-performing assets, Macroeconomic determinants, banks specific determinants

\section{Introduction}

The Non Performing Loans (NPLs) of Indian Banking sector are continuously increasing. According to Nair and lyer (2016), the NPAs of the listed banks in India increased by Rs. 1 trillion in the last quarter of 2015. The aggregate net profit of the 39 listed banks fell $98 \%$ to Rs.307 crore in the December quarter from Rs.16,806 crore in the year earlier. The provisions made towards NPAs and loss assets wiped out the profits of these listed banks. Out of the 27 banks that reported a quarterly profit, six saw profits plummet more than $70 \%$ from a year-ago period (Nair and lyer, 2016).

The high levels of NPLs have devastating consequences on the banks profitability. Most of the banks are getting losses. There is also the risk of bank failure 
and if this happens then there is risk for the entire economy. Therefore it is necessary to study the factors responsible for high levels of NPAs in the Indian Banking Sector (Swamy, 2012).

Determinants of NPAs in India, has received inadequate attention of the researchers. There is research on other countries of the world like Tunisia, Ghana etc.

\section{Literature Review}

Louzis, Vouldis, and Metaxas (2012) and Abid, Ouertani and Ghorbel (2014) used dynamic panel data model to study the factors influencing non-performing loans (NPLs) in the Greek and Tunisian banking sector respectively. Louzis, Vouldis, and Metaxas (2012) studied separately Non-Performing Assets (NPAs) for consumer credit, corporate credit and secured loans. Both the studies are based on the hypothesis that both macroeconomic and bank-specific variables increase NPAs. The results demonstrate that, NPLs can be explained mainly by macroeconomic variables which include GDP, unemployment, interest rates and public debt and also by management quality.

Kauko (2012) tests the significance of current account deficits to banking crisis. Focus is on the worsening credit quality. When the borrower's payments are dues on loans it is normally classified as non-performing loan. Excessive credit growth frequently precedes banking crises (see e.g. Borio and Lowe, 2002; Demirgüç-Kunt and Detragiache, 2005 or Davis and Karim, 2008 cited in Kauko 2012). Taking a cross section data of 34 advanced countries with NPL as dependent variable and current account deficit, credit growth, income per capita, inflation and money stock before crisis as independent variables they tried to find out whether credit growth and current account deficits are causing banking crisis. They found that both credit growth and current account deficits cause banking crisis. One more interesting findings of theirs is credit growth causes banking crisis only when there is corresponding current account deficit in the country. Otherwise it is not causing banking crisis.

Alhassan, Coleman and Andoh (2014), aims to study the determinants of worsening in the asset quality of Ghanaian banks during a period of financial crises i.e. 2005 to 2010, using a panel dataset of 25 banks. Using the method of Generalized Method of Moments estimations, they find that addition to credit increase, bank market structure, bank size, inflation, real exchange rate and GDP growth are the also important factors of banks asset quality in Ghana.

\section{Macroeconomic and Bank specific Determinants of NPAs}

In the literature determinants of NPAs are categorized into macroeconomic factors and bank specific factors. Macroeconomic factors include GDP per capita, inflation, interest rates, business cycles etc Kauko (2012), Louzis, Vouldis, and Metaxas (2012) and Abid, Ouertani and Ghorbel (2014). Many researchers have studied the link between macroeconomic variables like GDP and inflation and NPAs (Abid, Ouertani and Ghorbel, (2014), Kauko (2012), Louzis, Vouldis, and Metaxas

\section{$-126-$}


(2012) ). It has been accepted that at the expansionary stage of the economy, NPAs are relatively low because both consumers and firms' revenues are increasing and they therefore pay off their debts. But during the recessionary period banks tend to allocate credit even to poor quality borrowers and consequently bad debts multiply. Lis, et.al.,(2000) have found that Gross Domestic Product growth had negative effect on NPAs, because of increasing income levels businesses repay their debts and NPAs will decline. Inflationary pressures in Sub-Saharan African countries have led to increasing bad loans (Fofack (2005)).

Rate of unemployment is also another macroeconomic variable impacting NPAs (Rinaldi and Sanchis-Arellano (2006)). Research has proved that there is relationship between inflation rate and default rate as well.

Berger and Deyoung (1997), Louzis et al (2012) and many other researchers along with macroeconomic factors as determinants of NPLs also considered bank specific variables. In fact, they considered large number of bank specific variables as the determinants of NPLs. According to Sergio (1996), an increase in the riskiness of loan assets is rooted in a bank's lending policy, like relatively unselective and inadequate assessment of prospects of the companies and sectors. According to Berger and Deyoung (1997) and Louzis et al's (2012) bad management, skimping and moral hazard also lead to high NPAs. Bad management policies include inefficient credit scoring, bad control and follow up of borrowers, and lack of collaterals or bad collaterals. Skimping implies less effort banks devote to ensure higher loan quality, the more cost-efficient they will be and the more the number of NPLs will be in the long term. Moral hazard' hypothesis looks into the amount of capital available with the banks. It assumes that banks' low-capitalization causes more of NPLs. Other bank specific factors have an impact on NPLs are banks' diversification opportunity and bank size. The link between bank specific factors and NPLs is ambiguous in its direction. According to Hu et al (2004), big banks allow managers to appraise loan and devote more resources to see that loan does not become bad. Bank size is negatively related with NPLs. This implies that bigger banks have lesser NPAs since they have greater capacity to control NPLs and also they have good management i.e. their credit scoring and other standards followed for loan disbursements will be more rigorous (Salas and Saurina (2002) Alhassan, Coleman and Andoh, (2014)).

Bank ownership is also one of the variable determining NPAs of the banking sector. It is generally believed that private sector is more efficient that the public sector. In India we have banks of public sector banks, private sector banks and foreign banks. In India after 1992, all the three categories of banks are subjected to same prudential and regulatory norms and therefore a level playing field was created (Bhaumik and Dimova, 2003). Bhaumik and Dimova (2003), found that public sector banks performance is in no way inferior to the private sector banks. Sarkar et al. (1998) found some weak evidence to put forward that ownership was a significant determinant of performance. However, they used data of nineties. 


\section{Objectives of the Study}

The primary objective of the paper is to study the factors responsible for high level of NPAs in the Indian banking sector. The secondary objectives are:

- To find out whether the determinants of NPAs are same across different categories of banks i.e. government banks, private banks and foreign banks, or not

- To examine whether priority sector lending is leading to NPAs of banking sector.

- To study the bank specific factors, like size and total lending of the bank

- To study the impact of macroeconomic variables like Percapita GDP (PCY) and inflation (INFN) on NPAs of different categories of banks.

\section{Methodology}

Panel Data of all the banks in India other macro economic variables is collected from official website of Reserve Bank of India over the period from 2005 to 2014 for all the banks in India. Banks are then diveided into three categories viz., public sector banks (PSBs), private banks (PBs) and Foreign Banks (FBs). The data on Percapita GDP (PCY) and inflation (infn) is taken from RBI website. The data on $P C Y$ is converted to natural logarithms (LPCY) to avoid unit root problem. The variable used and their definitions are tabulated in table 1.

In the second stage yearly Average NPAs are calculated separately for public sector banks (PSBs), private banks (PBs) and Foreign Banks (FBs). PSBs are again divided into two categories viz., SBI and its Associates and Nationalized Banks.

In the third stage correlations amongst the variables is computed.

In the fourth and the final stage panel data regressions (both fixed and random) analysis is done separately for the three categories of banks to find out the significant variables on which NPAs depend and a comparative analysis is done.

\section{Hypothesis}

The main hypotheses are

$\mathrm{H} 1$ : Priority Sector lending is one of the causes for NPAs in India.

Banks in India are under regulatory obligation of devote a certain percentage of their loans to priority sector, which includes agriculture and allied activities, small and medium enterprises, educational and housing loans with certain caps. There are apprehensions that those banks which lend a large percentage of their loans to priority sector have more NPAs compared to other banks (Swamy, 2012).

$\mathrm{H} 2$ : The banks which diversify their operations will have lesser NPAs or diversification hypothesis. 
Table 1: Variable used, their definitions and expected sign

\begin{tabular}{|c|l|l|l|}
\hline \multicolumn{4}{|c|}{ Definition of variables used to test the various hypotheses. } \\
\hline Varible & Definition & Hypothesis Tested & $\begin{array}{l}\text { Expected } \\
\text { sign }\end{array}$ \\
\hline LPCY & $\begin{array}{l}\text { Natural Logarithm of Percapita } \\
\text { GDP at Factor Cost }\end{array}$ & Higher the PCY lower the NPAs & Negative \\
\hline INFN & Inflation rate & $\begin{array}{l}\text { Higher the inflation rate lower is } \\
\text { the NPAs }\end{array}$ & Negative \\
\hline SIZE & $\begin{array}{l}\text { Ratio of total assets of the bank } \\
\text { to total assets of the banking } \\
\text { sector }\end{array}$ & $\begin{array}{l}\text { Bigger banks have lesser NPAs } \\
\text { than smaller banks }\end{array}$ & Negative \\
\hline TLTLBS & $\begin{array}{l}\text { Ratio of total loans of the bank to } \\
\text { total loans of the banking sector }\end{array}$ & $\begin{array}{l}\text { The banks which diversify their } \\
\text { operations will have lesser NPAs } \\
\text { or diversification hypothesis. }\end{array}$ & Positive \\
\hline PSTL & $\begin{array}{l}\text { Ratio of priority sector lending to } \\
\text { total lending }\end{array}$ & $\begin{array}{l}\text { Priority Sector lending is one of } \\
\text { the causes for NPAs in India }\end{array}$ & Positive \\
\hline
\end{tabular}

Following Louzis, Vouldis, and Metaxas (2012), if banks diversify their business thay have lesser NPAs. But the relation between the two is unclear and ambigous. For this purpose we have taken the ratio of total loan of the bank to the total loan of the banking sector (tttlbs).

H3: Bigger banks have lesser NPAs than smaller banks

It has been widely accepted that bigger banks perform better and therefore their NPA level will be less, compared to smaller banks. We have measured size as a ratio of total assets of the bank to the total assets of the banking sector.

$\mathrm{H} 4$ : Higher the PCY lower the NPAs

Following (Abid, Ouertani and Ghorbel, 2014) and (Louzis, Vouldis, and Metaxas, 2012) percapita income is the major macro economic factor influencing NPAs in the banksing sector.

H5: Higher the inflation rate lower is the NPAs.

Following (Abid, Ouertani and Ghorbel, 2014) and (Louzis, Vouldis, and Metaxas, 2012) INFN is the major macro economic factor influencing NPAs in the banksing sector.

Variable used, their definitions and expected sign of the coefficient is summarized in the table 1 below.

\section{Results and Discussion}

\section{Average NPAs of Foreign Banks, Private Banks, Nationalised Banks and SBI and its Associates \\ The average NPAs in four different categories of banks Viz, Foreign banks,} private sector banks, nationalised banks and $\mathrm{SBI}$ and its associates, is shown in table 2 below: 
Table 2: Average NPAs of Foreign Banks, Private Banks, Nationalised Banks and $\mathrm{SBI}$ and its Associates (in INR millions)

\begin{tabular}{|c|c|c|c|c|c|}
\hline & $\begin{array}{l}\text { FOREIGN } \\
\text { BANKS }\end{array}$ & $\begin{array}{l}\text { PRIVATE } \\
\text { BANKS }\end{array}$ & $\begin{array}{l}\text { NATIONALISED } \\
\text { BANKS }\end{array}$ & $\begin{array}{l}\text { SBI \& ITS } \\
\text { ASSOCIATES }\end{array}$ & $\begin{array}{l}\text { Total } \\
\text { Average }\end{array}$ \\
\hline 2005 & $\begin{array}{r}206.15 \\
(1.39 \%)\end{array}$ & $\begin{array}{l}1452.26 \\
(9.76 \%)\end{array}$ & $\begin{array}{r}5270.35 \\
(35.41 \%)\end{array}$ & $\begin{array}{r}7953.56 \\
(53.44 \%)\end{array}$ & $\begin{array}{r}14882.32 \\
(100 \%) \\
\end{array}$ \\
\hline 2006 & $\begin{array}{r}278.50 \\
(2.10 \%)\end{array}$ & $\begin{array}{l}1132.25 \\
(8.55 \%)\end{array}$ & $\begin{array}{r}4246.72 \\
(32.06 \%)\end{array}$ & $\begin{array}{r}7590.13 \\
(57.29 \%)\end{array}$ & $\begin{array}{r}13247.58 \\
(100 \%)\end{array}$ \\
\hline 2007 & $\begin{array}{r}319.83 \\
(2.23 \%)\end{array}$ & $\begin{array}{r}1611.26 \\
(11.22 \%)\end{array}$ & $\begin{array}{r}4482.84 \\
(31.21 \%)\end{array}$ & $\begin{array}{r}7949.13 \\
(55.34 \%)\end{array}$ & $\begin{array}{r}14363.05 \\
(100 \%)\end{array}$ \\
\hline 2008 & $\begin{array}{r}445.22 \\
(2.45 \%)\end{array}$ & $\begin{array}{r}2455.19 \\
(13.49 \%)\end{array}$ & $\begin{array}{r}4663.77 \\
(25.62 \%)\end{array}$ & $\begin{array}{l}10636.16 \\
(58.44 \%)\end{array}$ & $\begin{array}{r}18200.34 \\
(100 \%)\end{array}$ \\
\hline 2009 & $\begin{array}{r}415.99 \\
(1.70 \%)\end{array}$ & $\begin{array}{r}3369.10 \\
(13.78 \%)\end{array}$ & $\begin{array}{r}5143.15 \\
(21.03 \%)\end{array}$ & $\begin{array}{l}15527.33 \\
(63.49 \%)\end{array}$ & $\begin{array}{r}24455.57 \\
(100 \%)\end{array}$ \\
\hline 2010 & $\begin{array}{r}930.38 \\
(3.04 \%)\end{array}$ & $\begin{array}{l}2957.27 \\
(9.66 \%)\end{array}$ & $\begin{array}{r}8406.55 \\
(27.45 \%)\end{array}$ & $\begin{array}{l}18329.03 \\
(59.85 \%)\end{array}$ & $\begin{array}{r}30623.22 \\
(100 \%)\end{array}$ \\
\hline 2011 & $\begin{array}{r}386.02 \\
(1.02 \%)\end{array}$ & $\begin{array}{l}2110.55 \\
(5.59 \%)\end{array}$ & $\begin{array}{l}10631.98 \\
(28.14 \%)\end{array}$ & $\begin{array}{l}24650.98 \\
(65.25 \%)\end{array}$ & $\begin{array}{r}37779.53 \\
(100 \%)\end{array}$ \\
\hline 2012 & $\begin{array}{r}344.49 \\
(0.62 \%)\end{array}$ & $\begin{array}{l}2200.61 \\
(3.95 \%)\end{array}$ & $\begin{array}{l}19484.29 \\
(34.94 \%)\end{array}$ & $\begin{array}{l}33727.70 \\
(60.49 \%)\end{array}$ & $\begin{array}{r}55757.09 \\
(100 \%)\end{array}$ \\
\hline 2013 & $\begin{array}{r}619.20 \\
(0.76 \%)\end{array}$ & $\begin{array}{l}2997.19 \\
(3.68 \%)\end{array}$ & $\begin{array}{l}30925.44 \\
(38.00 \%)\end{array}$ & $\begin{array}{l}46834.55 \\
(57.55 \%)\end{array}$ & $\begin{array}{r}81376.37 \\
(100 \%)\end{array}$ \\
\hline 2014 & $\begin{array}{r}737.47 \\
(0.63 \%)\end{array}$ & $\begin{array}{l}4430.77 \\
(3.79 \%)\end{array}$ & $\begin{array}{l}42164.93 \\
(36.03 \%)\end{array}$ & $\begin{array}{l}69691.83 \\
(59.55 \%)\end{array}$ & $\begin{array}{r}117025.00 \\
(100 \%)\end{array}$ \\
\hline 2015 & $\begin{array}{r}399.24 \\
(0.31 \%)\end{array}$ & $\begin{array}{l}7064.16 \\
(5.51 \%)\end{array}$ & $\begin{array}{l}58538.32 \\
(45.69 \%)\end{array}$ & $\begin{array}{l}62129.55 \\
(48.49 \%)\end{array}$ & $\begin{array}{r}128131.27 \\
(100 \%)\end{array}$ \\
\hline
\end{tabular}

The average NPAs in foreign banks worked out to be 206millions in 2005, which constituted only $1.4 \%$ of total all India average. Their percentage increased to $3 \%$ in 2010 . From 2011, it continously declined and in 2015 it was only $0.31 \%$. For private sector banks the figure was 1452 millions, which was $9.8 \%$ of the all India average. In 2009, their percentage also increased to 14 , but were soon able to control it and in 2015 it stood at $5.5 \%$. For nationalized banks it was 5270 millions, which was $35 \%$ of all India average. It slowly declined but increased to $46 \%$ in 2015 . For SBI and its Associates it was 7953.56 millions, which was $53 \%$ of the total avarage. The percentage kept increasing till 2014 and in 2015 it declined to $48 \%$. Publich sector banks together constituted alsmost $94 \%$ of total averge NPAs and only $6 \%$ is by private sector banks and foreign banks.

The diagram shows that SBI and its associate banks have very high NPAs, followed by nationalised banks and private sector banks. Foreign banks have consistently maintained low NPAs. 
Diagram 1

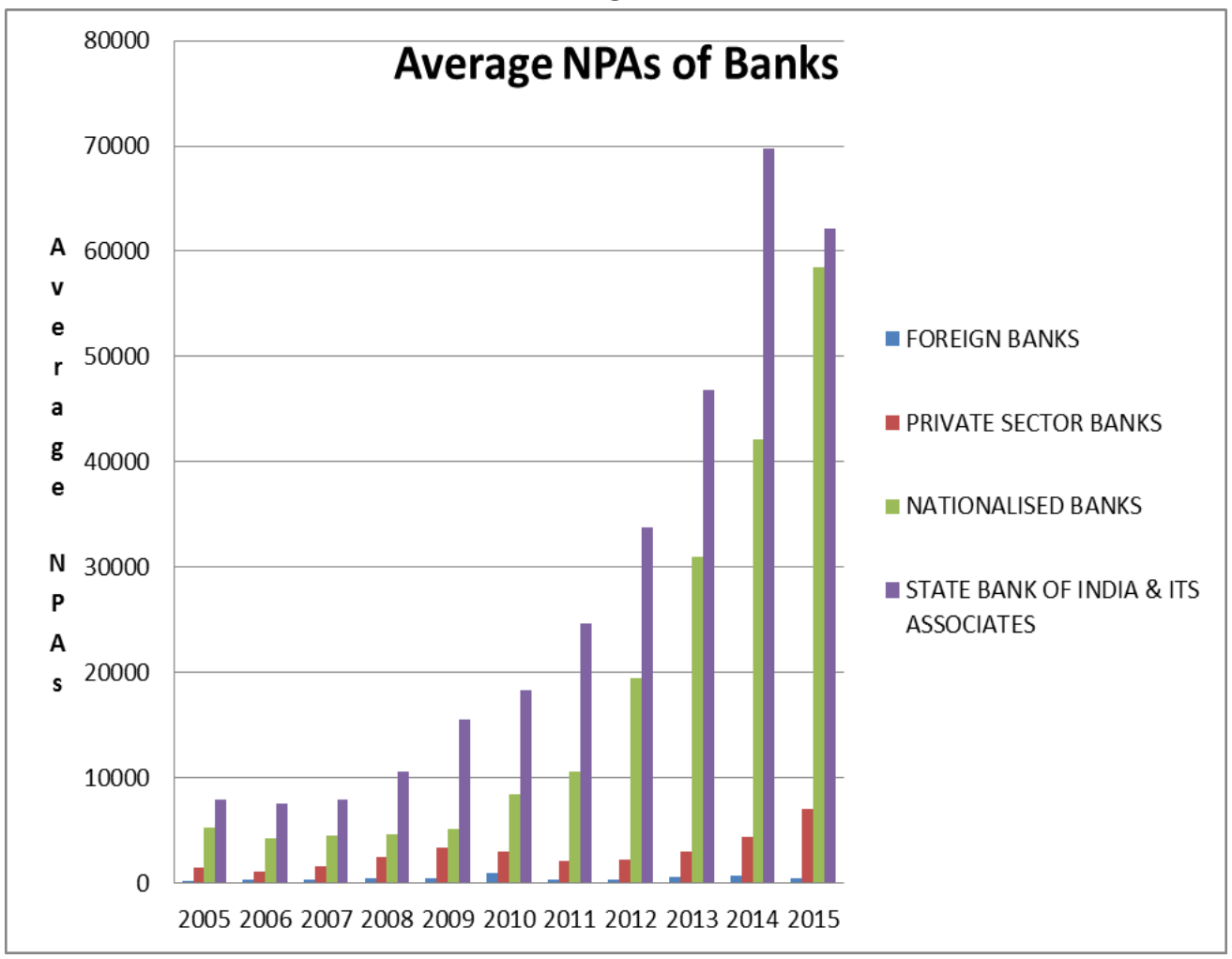

\section{Correlations}

Table 3 gives correlations amongst the variables for State Owned Banks. The table shows that NPATA is highly correlated with LPCY. There is also significant correlation between LPCY and INFN, TLTLBS and PSTL and PSTL and size.

Table 3: Correlations

\begin{tabular}{|l|c|c|c|c|c|c|}
\hline \multicolumn{7}{|c|}{ Correlations for PSBs } \\
\hline & NPATA & LPCY & Infn & TLTLBS & PSTL & Size \\
\hline NPATA & 1 & & & & & \\
\hline LPCY & $.367\left(^{* *}\right)$ & 1 & & & & \\
\hline Infn & -0.057 & $.494\left(^{* *}\right)$ & 1 & & & \\
\hline TLTLBS & 0.053 & 0.027 & 0.019 & 1 & & \\
\hline PSTL & 0.024 & -0.047 & -0.026 & $.964\left({ }^{* *}\right)$ & 1 & $.980\left(^{* *}\right)$ \\
\hline Size & 0.05 & 0.005 & 0.005 & $.994\left(^{* *}\right)$ & 1 \\
\hline \multirow{2}{*}{} & \multicolumn{7}{|c|}{ Correlation is significant at the 0.01 level (2-tailed). } \\
\hline$*$ & Correlation is significant at the 0.05 level (2-tailed). \\
\hline
\end{tabular}


Table 4 gives correlations amongst variables for PSBs. We find that there is significant and negative correlation of NPATA with LPCY and INFN. Correlation is negative with other variables as well, but not significant. There is significant correlation between LPCY and INFN, TLTLBS and PSTL and PSTL and size

Table 4

\begin{tabular}{|l|c|c|c|c|c|c|}
\hline \multicolumn{7}{|c|}{ Correlations for PBs } \\
\hline & NPATA & LPCY & Infn & TLTLBS & PSTL & Size \\
\hline NPATA & 1 & & & & & \\
\hline LPCY & $-.356\left(^{* *}\right)$ & 1 & & & & \\
\hline Infn & $-.218\left(^{* *}\right)$ & $.494\left(^{* *}\right)$ & 1 & & & \\
\hline TLTLBS & -0.099 & -0.009 & -0.012 & 1 & & \\
\hline PSTL & -0.117 & 0.002 & 0 & $.977\left(^{* *}\right)$ & 1 & $.98\left(^{* *}\right)$ \\
\hline Size & -0.114 & 0.022 & 0.005 & $.99\left(^{* *}\right)$ & 1 \\
\hline$* *$ & \multicolumn{7}{|c|}{ Correlation is significant at the 0.01 level (2-tailed). } & \\
\hline
\end{tabular}

Table 5 gives correlations amongst variables for Foreign Banks. For Foreign banks we find that LPCY and INFN are negatively correlated to NPATA but are not significant. Other variables like TLTLBS and PSTL are positive and significant. This implies that as the ratio of TLTLBS and PSTL increase NPAs also increase. This is in consonance to the generally held view that as the total loans of the bank increases its NPA will also increase. Similarly for the PSTL as well.

Table 5

\begin{tabular}{|c|c|c|c|c|c|c|}
\hline \multicolumn{7}{|c|}{ Correlations for FBs } \\
\hline & NPATA & LPCY & Infn & TLTLBS & PSTL & Size \\
\hline NPATA & 1 & -0.026 & -0.072 & $.299\left(^{* \star}\right)$ & $.537\left(^{* *}\right)$ & -0.122 \\
\hline LPCY & -0.026 & 1 & $\left..493^{(*}\right)$ & -0.087 & -0.011 & 0.014 \\
\hline $\operatorname{Infn}$ & -0.072 & $.493\left(^{* \star}\right)$ & 1 & -0.048 & 0.022 & 0.022 \\
\hline TLTLBS & $.299\left(^{* *}\right)$ & -0.087 & -0.048 & 1 & $\left..912^{(*}\right)$ & $.292\left(^{* \star}\right)$ \\
\hline PSTL & $.537\left(^{* *}\right)$ & -0.011 & 0.022 & $.912\left(^{* *}\right)$ & 1 & $.175\left(^{*}\right)$ \\
\hline Size & -0.122 & 0.014 & 0.022 & $\left..2922^{* *}\right)$ & $.175\left(^{*}\right)$ & 1 \\
\hline ** & \multicolumn{6}{|c|}{ Correlation is significant at the 0.01 level (2-tailed). } \\
\hline * & \multicolumn{6}{|c|}{ Correlation is significant at the 0.05 level (2-tailed). } \\
\hline
\end{tabular}

\section{Regression Results}

Table 6 gives results of panel data regression for SOBs, PSBs and FBS. It gives the coefficients for both fixed effects and random effects model and $t$-value is given in the parenthesis. 
Table 6

\begin{tabular}{|c|c|c|c|c|c|c|}
\hline & \multicolumn{2}{|c|}{ Government Banks } & \multicolumn{2}{|c|}{ Private Sector Banks } & \multicolumn{2}{|c|}{ Foreign Banks } \\
\hline Variable & $\begin{array}{c}\text { Fixed } \\
\text { Effect } \\
\text { Coefficient }\end{array}$ & $\begin{array}{c}\text { Rabdom } \\
\text { Effect } \\
\text { Coefficient }\end{array}$ & $\begin{array}{c}\text { Fixed } \\
\text { Effect } \\
\text { Coefficient }\end{array}$ & $\begin{array}{l}\text { Rabdom } \\
\text { Effect } \\
\text { Coefficient }\end{array}$ & $\begin{array}{c}\text { Fixed } \\
\text { Effect } \\
\text { Coefficient }\end{array}$ & $\begin{array}{c}\text { Random } \\
\text { Effect } \\
\text { Coefficient }\end{array}$ \\
\hline $\mathrm{C}$ & $\begin{array}{c}-0.176341 \\
(-6.43)\end{array}$ & $\begin{array}{c}-0.15378 \\
(-7.20)\end{array}$ & $\begin{array}{c}0.141691 \\
(6.37)\end{array}$ & $\begin{array}{c}0.133541 \\
(6.16)\end{array}$ & $\begin{array}{c}-0.01342 \\
(-0.23)\end{array}$ & $\begin{array}{c}-0.00322(- \\
0.06)\end{array}$ \\
\hline LPCY & $\begin{array}{c}0.019074 \\
(7.25)\end{array}$ & $\begin{array}{c}0.016068 \\
(7.66)\end{array}$ & $\begin{array}{c}-0.01286(- \\
5.80)\end{array}$ & $\begin{array}{c}-0.01196 \\
(-5.59)\end{array}$ & $\begin{array}{c}0.001927 \\
(0.34)\end{array}$ & $\begin{array}{c}0.001272 \\
(0.23)\end{array}$ \\
\hline INFN & $\begin{array}{c}-0.001428 \\
(-4.63)\end{array}$ & $\begin{array}{c}-0.00121 \\
(-4.66)\end{array}$ & $\begin{array}{c}-0.00024(- \\
0.92)\end{array}$ & $\begin{array}{c}-0.00025 \\
(-0.96)\end{array}$ & $\begin{array}{c}-0.00077 \\
(-1.11)\end{array}$ & $\begin{array}{c}-0.00074(- \\
1.07)\end{array}$ \\
\hline SIZE & $\begin{array}{c}-0.364082 \\
(0.71)\end{array}$ & $\begin{array}{c}0.109217 \\
(0.67)\end{array}$ & $\begin{array}{c}0.557978 \\
(1.71)\end{array}$ & $\begin{array}{c}0.200388 \\
(0.89)\end{array}$ & $\begin{array}{c}1.881845 \\
(1.13)\end{array}$ & $\begin{array}{c}-0.19926(- \\
0.21)\end{array}$ \\
\hline TLTLBS & $\begin{array}{c}0.142913 \\
(-1.02)\end{array}$ & $\begin{array}{c}-0.06976 \\
(-0.59)\end{array}$ & $\begin{array}{c}-0.32883(- \\
1.74)\end{array}$ & $\begin{array}{c}-0.19082 \\
(-1.08)\end{array}$ & $\begin{array}{c}0.153806 \\
(0.18)\end{array}$ & $\begin{array}{c}-0.20451(- \\
0.24)\end{array}$ \\
\hline PSTL & $\begin{array}{c}-0.252222 \\
(-0.83\end{array}$ & $\begin{array}{c}-0.03481 \\
(-0.13)\end{array}$ & $\begin{array}{c}-0.38561 \\
(0.68)\end{array}$ & $\begin{array}{c}-0.04207 \\
(-0.09)\end{array}$ & $\begin{array}{c}-3.75216(- \\
0.58)\end{array}$ & $\begin{array}{c}1.50934 \\
(0.28)\end{array}$ \\
\hline R-squared & 0.35 & 0.16 & 0.54 & 0.20 & 0.25 & 0.007 \\
\hline $\begin{array}{c}\text { Hausman Chi } \\
\text { p-value in } \\
\text { paranthesis }\end{array}$ & \multicolumn{2}{|c|}{$1.999966(0.85)$} & \multicolumn{2}{|c|}{$5.008376(0.4149)$} & \multicolumn{2}{|c|}{$4.92066(0.4256)$} \\
\hline
\end{tabular}

The Hausman test results reveal that Fixed Effect model is suitable to all the three categories of banks. However, the results of both fixed and random effects are presented in the table. The results of PSU Banks suggest that LPCY and INFN are the significant variables affecting the NPAs of banks. The coefficient of LPCY has got positive sign which as contradictory to the expected sign for the variable. The reason may be that during rising income levels there will be more demand for loans and there are chances that banks will be sanctioning loans without proper scrutiny (Abid, Ouertani and Ghorbel, 2014) (Louzis, Vouldis, and Metaxas, 2012).

For PSBs LPCY is highly significant, while TLTLBS and Size is significant at $10 \%$ level. The coefficient of size has got positive sign, which is again contradictory to the expected sign. This implies that bigger banks are having higher NPAs. The ratio of TLTLBS also has got negative sign and is against the expected sign for the coefficient. PSTL is not significant but has got negative sign which means that higher loans to priority sector is leading to lesser NPAs. It implies that the main defaulters of banks loans are not small borrowers but the bigger borrowers who do not fall in the priority sector. The case of Vijay Malliya proves this point. In case of foreign banks, none of the variables are significant. Thus we find that the determinants of NPAs vary according to its ownership.

\section{Conclusion}

From the results of the panel data analysis it can be concluded that the determinants of NPLs in the banking sector vary across ownership structure of banks. No single set of variables can be generalized for all the banks. The results show that 
Macro economic factors, like log of percapita income (LPCY) and Inflation (INFN), are significantly affecting NPLs in Public Sector Banks (PSBs). In case of private banks (PBs) LPCY is highly significant while bank specific variables like size and total loans to total loans of the banking sector (TLTLBS) are significant at $10 \%$ level. For FBs none of the variables were significant. A further research is needed to study for FBs are able to keep their NPLs at a lower level.

\section{References}

Abid, Ouertani and Ghorbel. (2014). Macroeconomic and Bank-Specific Determinants of Household's Non-Performing Loans in Tunisia: a Dynamic Panel Data. In T. S. (TSFS) (Ed.), Procedia Economics and Finance 13. 13, pp. 58-68. Tunisia: Elsevier.

Alhassan, Coleman and Andoh. (2014). Asset quality in a crisis period: An empirical examination of Ghanaian banks. Review of Development Finance , 4 (1), 50-62.

Berger and Deyoung. (1997). Problem Loans and Cost Efficiency in Commercial Banks. Journal of Banking and Finance , 21 (1), 1-28.

Bhaumik and Dimova. (2003). How important is ownership in a market with level playing field?The Indian banking sector revisited. Journal of Comparative Economics , 32, 165180.

Boyd, J and M Gertler (1993): "US Commercial Banking: Trends, Cycles, and Policy", NBER Working Paper 4404.

Fofack, Hippolyte, Nonperforming Loans in Sub-Saharan Africa: Causal Analysis and Macroeconomic Implications (November 2005). World Bank Policy Research Working Paper No. 3769. Available at SSRN: HYPERLINK "http://ssrn.com/abstract=849405" It "_blank" http://ssrn.com/abstract=849405

Fischer, O. B. (Ed.). (1993). Commercial Banking: Trends, Cycles, and Policy. NBER Macroeconomics Annual 1993 (pp. 319 - 377). MIT Press.

$\mathrm{Hu}$, J.L., Li, Y., Chiu, Y.H. (2004), Ownership and nonperforming loans: Evidence from Taiwan's banks. The Developing Economies, 42(3), 405-420.

Kauko, K. (2012). External deficits and non-performing loans in the recent financial crisis. Economics Letters , 115, 196-199.

BIBLIOGRAPHY V 1033

Louzis, Vouldis, and Metaxas. (2012). Macroeconomic and bank-specific determinants of nonperforming loans in Greece: A comparative study of mortgage, business and consumer Ioan portfolios. Journal of Banking \& Finance , 36, 1012-1027.

Nair and lyer. (2016). Listed banks' NPAs surge by Rs1 trillion in December quarter. Live Mint. URL link: HYPERLINK "http://www.livemint.com/Industry/ZQhav7x8FESxfLT1tHp0aO/Listed-banks-NPAssurge-by-Rs1-trillion-in-December-quarter.html" http://www.livemint.com/Industry/ZQhav7x8FESxfLT1tHp0aO/Listed-banks-NPAssurge-by-Rs1-trillion-in-December-quarter.html

Podpiera and Weillil. (2008). Bad luck or bad management? Emerging banking market experience. Journal of Financial Stability , 4 (2), 135-148.

Rajan and Dhal. (2003). Non-Performing Loans and Terms of Credit ofPublic Sector Banks in India:An Empirical Assessment. Reserve Bank of India (RBI).

Reddy, P. K. (2002, October). A comparative study of Non Performing Assets in India in the Global context - similarities and dissimilarities, remedial measures. SSRN working 
paper available at http://ssrn.com/abstract=361322 or http://dx.doi.org/10.2139/ssrn.361322, 1-16.

Rinaldi and Sanchis-Arellano (2006) " Household Debt Sustainability What Explains Household Non-Performing Loans? An Empirical Analysis" European Central Bank Working Paper series No. 570, Jan 2006 available at https://www.ecb.europa.eu/pub/pdf/scpwps/ecbwp570.pdf?2546b8e00ce934b13cfe47c 36da5bc45

Salas and Saurina. (2002). Credit Risk in Two Institutional Regimes: Spanish Commercial and Savings Banks. Journal of Financial Services Research , 22 (3).

Stiroh, K. J. (2004). Diversification in Banking: Is Noninterest Income the Answer? Journal of Money, Credit and Banking , 36 (5), 853-882.

Swamy, Vighneswara (2012) "Impact of macroeconomic and endogenous factors on non performing bank assets," International Journal of Banking and Finance: Vol. 9: Iss. 1.

(2015). Trends and Progress in Banking. RBI. RBI. available on https://rbidocs.rbi.org.in/rdocs/Publications/PDFs/0FLTP577BF4E172064685A26A73A6 BC9210EC.PDF

Weill's, P. a. (2008). Bad luck or bad management? Emerging banking market experience. Journal of Financial Stability , 4 (2), 135-148. 